\title{
THE INFLUENCE OF THE QUESTION BOX MEDIA ASSISTED TEAMS GAMES TOURNAMENT MODEL ON SCIENCE LEARNING OUTCOMES AT ELEMENTARY SCHOOL
}

\author{
Zulherman* \\ Khairil Iba \\ Andhini Ayu Paramita \\ Supriansyah \\ Galih Baskoro Aji \\ Primary Education, Faculty of Teacher Training and Education, \\ Universitas Muhammadiyah Prof. DR. HAMKA \\ JL. Tanah Merdeka, Pasar Rebo, Jakarta, Indonesia \\ *E-mail: zulherman@uhamka.ac.id
}

Received: October29, 2020; Accepted: May 30, 2021

\begin{abstract}
This study aims to provide an empirical picture of whether or not the Teams GamesTournament (TGT) learning model aided by Question Box media has an impact on the fourthgrade science learning outcomes at SDN Cengkareng Barat 16 Pagi West Jakarta in the second semester of the 2018/2019 academic year. The research population consisted of 55 students consisting of 28 students of class IV A and 27 students of IV B. The sampling technique used is saturated sampling. This study used a quantitative approach, and the research method used was a quasi-experimental design with a Nonequivalent Posttest-Only Control Group Design. The result showed an effect of the Teams Games-Tournament (TGT) learning model assisted by the question box media on student learning outcomes in science.
\end{abstract}

Keywords: Learning model teams games-tournament; question box media; and science learning outcomes

\section{INTRODUCTION}

Education is one of the alternatives for cultural development and nation character builder to improve the quality of the nation's future generations so that later it can change the nation's life and solve all cultural problems and national character. In the era of globalization, every human must have superior abilities to fight in society. Through proper education, the nation's future generations expect to develop their potential to become qualified individuals and compete in society and the global world (Herpratiwi et al., 2019).

The generation of intelligence and character is one of the educational goals contained in the elementary school curriculum. Reference and guidelines in the implementation of education are a 
function of the curriculum. The curriculum, from time to time, always changes with the times. The current curriculum used is the 2013 curriculum. Nurdyansyah \& Fahyuni (2016) explain that the 2013 curriculum adheres to the fundamental view that knowledge cannot just transfer from teacher to student. Still, students are subjects who can actively seek, process, construct and use knowledge.

Generations who are intelligent and have character can achieve through education and teaching in various disciplines (Zulfadewina et al., 2020; Zulherman et al., 2020). One of these disciplines is Natural Sciences (IPA) (Hakim \& Syofyan, 2018). Natural Sciences, or what often referred to as science education, is one of the main subjects in Indonesia's education curriculum, including at the elementary school level. The implementation of learning in elementary science should emphasize understanding the concepts that are part of the science product and pay attention to the process of discovering these concepts (Kurniasih et al., 2020a; Permatasari \& Wahyudin, 2017). The learning process in schools empirically in Indonesia today mainly still refers to classical learning and depends on teachers' information (teacher center) (Zulherman, 2018).

Based on the observations made at SDN Cengkareng Barat 16 Pagi, science learning is considered difficult for students. This assumption is based on errors that occur due to several factors, namely errors originating from teachers' and students' misconceptions. Teachers have not implemented constructive learning is an error arising from the teacher, and students do not focus on following the learning process, which is an error arising from students. The learning process that often occurs in the classroom is still teacher-centered (teacher-centered), so students quickly feel bored and not absorbing the subject matter provided by the teacher. Thus no thought process makes students understand the material being studied. Besides, when the questions and answers were held, only a few students could answer questions from the teacher. When they are asked to read the results of their work, students do not participate actively in learning. Many are not confident in moving forward, so that the material presented is not as expected; this makes the quality of learning decline and will affect learning outcomes.

Implementing the 2013 curriculum states that learning is no longer centered on teachers, but learning is more centered on student activities (Muslim, 2020a). Because learning is more studentcentered; thus, learning is no longer one direction but more interactive (Sinambela, 2017). The teacher acts as a facilitator in learning. The teacher is required to be able to design learning to solve real and contextual problems. Design learning aims to use appropriate learning models and media to stimulate students to learn more. Choosing a learning model and media will positively impact students learning outcomes, especially learning that makes students active, creative and fosters cooperation in learning activities. One of the learning models that allow each student to be actively involved in science learning is the TGT learning model, and it will be more interesting if combined with the questions box media. 
The TGT learning model is constructivist. This model focuses on extracting student knowledge; in this learning model, students are expected to dig up critical information in their learning material. The TGT learning model is a type of cooperative learning that places students in study groups consisting of 5 to 6 students with different abilities, gender, and syllables or races (Baktini et al., 2019). According to Slavin (Primandari et al., 2019), the TGT type of cooperative learning consists of five stages, namely the class presentation stage, learning in groups (teams), games, matches (tournament), and group awards (teams recognition).

Taniredja (in Christian et al., 2018) this learning model is a student center with its advantages (1) students have the opportunity to interact with other students and express their opinions verbally, (2) can increase the confidence of each student, and annoying behavior of other students is reduced. In addition to having advantages, of course, this learning model has disadvantages, namely, (1) not all students in the active group have an opinion, (2) there is very little time, (3) the possibility of noise because it is not conditioned.

Given that the science material is very complex, it makes students feel bored quickly. One alternative that can overcome this problem is learning media as a tool that is expected to make students more active in learning. "Learning media is a tool that can help the teaching and learning process and serves to clarify the meaning of the message conveyed, so that it can achieve learning goals better and perfectly" (Septiawan et al., 2017). Learning media that can be used is the question box media.

A question box is a medium that provides a collection of questions related to the material that has been presented (Herpratiwi et al., 2019). Each information is poured into questions then put together in a box; these various questions serve as a quiz in learning. According to Syahlil (Astuti \& Kristin, 2017), the question box is an alternative media for teachers to stimulate students' emotional and intellectual involvement proportionally.

The TGT learning model is assisted by question box media. This learning model is very well used to involve students in analyzing material in-depth, with a cooperative way of working involving students' role as peer tutors and containing elements of play and reinforcement. This learning model is similar to the STAD learning model, except that groups of students are selected heterogeneously in this learning model. There are tournaments in the learning process to motivate students to support and help one another in mastering the skills taught by the learning model teacher. One member competes as the team's representative with other members whose previous academic performance equals this idea. Media Question Box is used in student tournaments as a tool for students to run the tournament. Based on the preliminary explanation, the research question is: Does the TGT learning model assisted by Question Box learning media affect grade IV elementary school students' science learning outcomes?. 


\section{METHOD}

This study used a quantitative approach, and the research method used is experimental. The type of experimental method used in this research is Quasi-Experimental Design because this study has a control group but cannot control external variables that affect the experiment (Kusumadewi et al., 2019). Researchers used the Nonequivalent Posttest-Only Control Group design. The subject is divided into two groups in the experimental method: the Experiment group in Class IV A and the control group in Class IV B. In this method, the researcher wants to look for significant differences in learning outcomes from science learning outcomes given treatment through the media-assisted Teams Games-Tournament learning model question box with untreated class.

The place of this research was carried out in class IV SDN Cengkareng Barat 16 Pagi. The research time was carried out in the even semester of the 2018/2019 academic year. The population used was all fourth-grade students of SDN Cengkareng Barat 16 Pagi, which consisted of two classes, each class IV A being the experiment class with 28 students and class IV B as the control class with 27 students. So the population in the study amounted to 55 students.

The sampling technique in this study is the Nonprobability Sampling Technique. (Sari et al., 2018) defines the nonprobability sampling technique as a sampling technique that does not provide equal opportunities for each element (member) of the population to be selected as a sample member. The sampling technique used in this study is saturated sampling, which means that all sample members become the research object.

It was collecting data in this study using tests that were tested after the learning process took place. The type of test used in this study is an objective test that requires an instrument to measure science learning outcomes. Before the instrument is used, the instrument is tested for validity first. The trial was conducted at SDN Pegadungan 11 Pagi in grade IV A. The number of students involved was 32 students with 50 items. This learning outcome test is made in a multiple-choice form.

The data analysis technique is analyzed from the students' post-test results after the learning process. Statistical analysis was carried out utilizing the analysis prerequisite test in the form of the normality test. The data normality test was conducted to determine whether the sample studied was normally distributed or not. The normality test conducted by researchers is the Lilliefors test. After the data is normally distributed, then the homogeneity test is carried out. The variance homogeneity requirement test is intended to show that the variances of the samples to be compared are not significantly different. The homogeneity test used was Fisher's test with a significant level of $\alpha=$ 0.05 . Because the $L<L_{\text {table }}$ and the variance results are homogeneous, so in testing the hypothesis, the t-test formula can be used. The t-test was conducted to determine whether or not there was an effect of the TGT learning model assisted by Question Box media on student learning outcomes with a significant $\alpha=0.05$ and $n_{1}+n_{2}-2$ degrees of freedom. 


\section{RESULT AND DISCUSSION}

The researcher tested the instrument before doing the research. The trial was conducted to determine the feasibility of the question instrument to be used as a research instrument. The trial was conducted in class IV, with 32 students with 50 questions. Based on Table 1, the classification of the test items for the science learning outcomes obtained valid questions totaling 34 items and 16 items dropping.

After knowing the number of valid question instruments, the reliability test was carried out, which amounted to 34 questions. Then the researchers calculated the reliability using the K.R 20 or Kuder Richardson formula. The reliability criteria are according to Zarkasyi (2017: 206) and are presented in Table 2.

Table 1. Classification of Question Items in Research Instrument Trial

\begin{tabular}{clcl}
\hline No & Classification & $\begin{array}{c}\text { Number of } \\
\text { Items }\end{array}$ & \multicolumn{1}{c}{ Item Number } \\
\hline 1 & Valid & 34 & $1,2,3,4,5,7,9,10,11,12,14,15,16,18,21,22,23,24$, \\
2 & Invalid & \multirow{2}{*}{16} & $25,26,28,29,31,35,37,38,39,40,41,42,46,47,48,50$ \\
& & $6,8,13,17,19,20,27,30,32,33,34,36,43,44,45,49$ \\
\hline
\end{tabular}

Table 2. The Criteria for Distinguishing Reliability

\begin{tabular}{ccc}
\hline No & Reliability Index & Category \\
\hline 1 & $\mathrm{R} 11 \leq 0,00$ & Very poor \\
2 & $0,00<\mathrm{R} 11 \leq 0,20$ & Poor \\
3 & $0,20<\mathrm{R} 11 \leq 0,40$ & Sufficient \\
4 & $0,40<\mathrm{R} 11 \leq 0,70$ & Good \\
5 & $0,70<\mathrm{R} 11 \leq 1,00$ & Very good \\
\hline
\end{tabular}

Table 3. Reliability Test Result

\begin{tabular}{cccc}
\hline $\mathbf{N}$ & $\boldsymbol{\alpha}$ & $\mathbf{r}_{11}$ & $\mathbf{C r i t e r i a}$ \\
\hline 30 & 0,05 & 0,9141 & Reliable \\
\hline
\end{tabular}

Based on the KR20 calculation in Table 3, $r_{11}$ score is 0,9141 . The instrument is reliable if $r_{11}>$ $r_{\text {table }}$ at the significance level of 0.05 with $\mathrm{n}=32$. Based on the results of the reliability test calculation, the results were obtained $r_{11}>r_{\text {table }}(0,9141>0,349)$. Thus, the calculation results are declared Reliable and have a very high interpretation. Most of the valid items were items that had been studied. Some invalid questions were mostly due to sentences that the students did not understand or had never studied before. Valid and reliable items will be used again for the post-test in the study.

The observation was done at SDN Cengkareng Barat 16 Pagi before researching to determine students' initial abilities. The research data obtained before conducting the research is in the form of a table of student scores in the previous subjects. The following data presented in Table 4. The data obtained show that an average class IV-A has an average value of 68.21, and class IV-B has an average value of 60.74 . 
Tabel 4. List of Student Scores Before Being Given The Treatment

\begin{tabular}{ccc}
\hline No. & Experiment Class & Control Class \\
\hline 1 & 60 & 50 \\
2 & 40 & 30 \\
3 & 30 & 60 \\
4 & 30 & 80 \\
5 & 90 & 50 \\
6 & 70 & 70 \\
7 & 90 & 100 \\
8 & 40 & 60 \\
9 & 90 & 30 \\
10 & 60 & 50 \\
11 & 100 & 70 \\
12 & 100 & 60 \\
13 & 90 & 70 \\
14 & 70 & 40 \\
15 & 60 & 60 \\
16 & 80 & 70 \\
17 & 30 & 50 \\
18 & 70 & 70 \\
19 & 50 & 40 \\
20 & 80 & 50 \\
21 & 60 & 60 \\
22 & 90 & 70 \\
23 & 80 & 70 \\
24 & 60 & 60 \\
25 & 60 & 80 \\
26 & 100 & 90 \\
27 & 50 & 50 \\
Average & 80 & \\
\hline & 68,21 & 74 \\
\hline
\end{tabular}

Table 5. Normality Test Result

\begin{tabular}{ccccc}
\hline Class & $\boldsymbol{L}$ & LTable & Criteria & Result \\
\hline Experiment & 0,0987 & 0,167 & $L<L_{\text {table }}$ & \multirow{2}{*}{ Normal } \\
Control & 0,1297 & 0,171 & \\
\hline
\end{tabular}

Science learning outcomes in classes using the TGT learning model assisted by Question Box media and in the untreated class using a learning outcome test totaled 34 items in an objective test on the post-test. Students' answers are given a score of 1 for the correct answer and 0 for the wrong answer.

Based on the calculation of the frequency distribution in the experiment group, the average score is obtained $\bar{X}=74,24$, while the control group received an average score $\bar{X}=61,57$ based on the data, it appears that the experiment class has a greater average value than the control class. The difference in the average value between the experiment class and the control class is 12.67 . The result proves that the mean value of the experiment class and control class is significantly different.

Data obtained from the normality test presented in Table 5 showed that $\mathrm{L}$ for the experiment group was 0.0987 . The value is then compared with the value $L_{\text {table }}$ with a significance level $=0.05$ in order to obtain a value $L=0,0987<0,167=L_{\text {table }}$ then $\mathrm{H} 0$ is accepted. So it can be concluded that 
the data in the experiment class are normally distributed. As for the control group, the value was obtained $L$ amounting to 0,1297 . The value is then compared with the value $L_{\text {table }}$ with significance $=0,05$ so that the value is obtained $L=0,1297<0,171=L_{\text {table }}$ then $\mathrm{H}_{0}$ is accepted. So it can be concluded that the data in the experiment class are normally distributed. Based on the data normality test analysis, below is a summary of the normality test results for the experiment and control classes using the Liliefors formula.

Table 6. Homogenity Test Result

\begin{tabular}{cccccc}
\hline Class & Variance & $\boldsymbol{F}$ & $\boldsymbol{F}_{\text {table }}$ & Criteria & Result \\
\hline $\begin{array}{c}\text { Experiment } \\
\text { Control }\end{array}$ & 170,82 & 1,196 & 1,925 & $F<F_{\text {table }}$ & Homogenous \\
\hline
\end{tabular}

Based on Table 6, which is displayed, the homogeneity test of variance was carried out on the experiment class and the control class. The homogeneity test used the $\mathrm{F}$ test at the significance level $=0.05$. From the calculation results obtained $F_{\text {table }}=1,925$. The value $F=1,196$ with df (degree of freedom) numerator $=28-1=27$ and df denominator $=27-1=26$. Because $F<F_{\text {table }}$ that is 1,196 $<1,925$, so $H_{0}$ is accepted. It can be concluded that the sample data in the experiment and control classes come from populations that have the same or homogeneous variants, so the data is declared homogeneous.

Table 7. t-test Result

\begin{tabular}{ccccc}
\hline df & $\boldsymbol{t}$ & $\boldsymbol{t}_{\text {table }}$ & Criteria & Result \\
\hline 58 & 3,69 & 2,006 & $t<t_{\text {table }}$ & Ho Rejected \\
\hline
\end{tabular}

Based on the t-test analysis results from Table 7, the average value of student learning outcomes using the Teams Games-Tournament learning model assisted by the question box media was 74.24 , with a standard deviation of 13.07. Meanwhile, the average value of science learning outcomes in the untreated class was 61.57 , with a standard deviation of 11.95 . The t-test analysis results were obtained $t_{\text {table }}=3,69$ at the significance level, $\alpha=0,05$ with the degree of freedom for 53 is 2,006. Because $t>t_{\text {table }}$ by $(3,69>2,006)$, it can be concluded that $H_{0}$ rejected and $H_{l}$ accepted, the data is stated to have an influence.

Based on the research results obtained, there is a significant difference in learning outcomes between the class treated with the TGT learning model assisted by the Question Box media and the class that was not given treatment. In line with this, the Teams Games-Tournament learning model assisted by question box media can have a better effect than conventional learning models (Endah, 2017). The Teams Games-Tournament learning model, assisted by question box media, encourages students to think from various perspectives. The subject matter used must also be considered, for example, in the material for preserving natural resources (Triowathi \& Wijayanti, 2018). In the learning material, there must be something that groups of students can analyze. 
This learning model is very well used to involve students in analyzing material in-depth, with a cooperative way of working involving students' role as peer tutors and containing elements of play and reinforcement (Muslim, 2020b). This learning model is similar to the STAD learning model, except that in this learning model, groups of students are selected heterogeneously, and there are tournaments in the learning process to motivate students to support and help one another in mastering the skills taught by the teacher (Azira, 2018). From this idea, one member competes as the team's representative with other members whose previous academic performance is equal to them. Media Question Box is used in student tournaments as a tool for students in the process of running the tournament (Kurniasih et al., 2020b). The research results that have been obtained above are in line with Antari \& Kusmariyatni (2020) research which states that the TGT learning model, assisted by Question Box media, has a significant effect on the competence of fifth-grade students.

\section{CONCLUSION AND SUGGESTION}

\section{Conclusion}

Based on the average score of science learning outcomes, it is known that science learning using the Teams Games-Tournament learning model assisted by Question Box media in grade IV A elementary student is better than science learning in class IV B who does not use the Teams GamesTournament assisted learning model media Question Box. The average value of science learning outcomes in class A (experiment) is higher than the average value of class B (control), namely 74.24> 61.57. It can be concluded that learning using the Teams Games-Tournament learning model assisted by Question Box media positively affects science learning outcomes.

\section{Suggestion}

There is a suggestion for this research. Further research is needed especially related to students' critical thinking skills. Research in case studies, for example, can be carried out with the aim of measuring the ability to understand the material being studied in more depth.

\section{REFERENCE}

Antari, N. P. J., \& Kusmariyatni, N. (2020). Penerapan Model Tgt Berbantuan Media Audio Visual Untuk Meningkat Hasil Belajar Ipa Siswa. Jurnal Ilmiah Pendidikan Dasar Indonesia, 1(1).

Astuti, W., \& Kristin, F. (2017). Penerapan Model Pembelajaran Teams Games Tournament Untuk Meningkatkan Keaktifan dan Hasil Belajar IPA. Jurnal Ilmiah Sekolah Dasar, 1(3), 155-162.

Azira, A. (2018). Pengaruh Model Pembelajaran Team Games Tournament (Tgt) Bermediakan Questions Box Terhadap Hasil Belajar Ipa. Journal for Lesson and Learning Studies, 1(3), 204-213.

Baktini, L. W., Rahayu, T. S., \& Wasitohadi, W. (2019). Pengaruh Model Teams Games Tournament dan Student Team Achievement Division terhadap Hasil Belajar IPA di Sekolah Dasar. JPDI (Jurnal Pendidikan Dasar Indonesia), 4(1), 24-28.

Christian, R. Y., Mawardi, M., \& Astuti, S. (2018). Perbedaan Hasil Belajar Matematika Menggunakan Model Student Team Achievment Divisions (Stad) Dan Teams Game 
Tournament (Tgt) Siswa Kelas 4 Sd. JTIEE (Journal of Teaching in Elementary Education), 2(1), 75-84.

Endah, N. (2017). Peningkatan Hasil Belajar Ipa Siswa Kelas 5 Sd Menggunakan Model Pembelajaran Kooperatif Tipe Tgt Berbantuan Media Gambar. JPsd (Jurnal Pendidikan Sekolah Dasar), 3(2), 96-104.

Hakim, S. A., \& Syofyan, H. (2018). Pengaruh Model Pembelajaran Kooperatif Tipe Teams Games Tournament (TGT) Terhadap Motivasi Belajar IPA di Kelas IV SDN Kelapa Dua 06 Pagi Jakarta Barat. International Journal of Elementary Education, 1(4), 249-263.

Herpratiwi, H., Erni Mustakim, E. M., ASTUTI, N., \& Qomario, Q. (2019). The Implementation of a Thematic Team Games Tournament-Cooperative Learning in the Fifth Grade of Elementary School in Lampung Province. International Journal of Innovation, Creativity and Change, 9(11), 192-205.

Kurniasih, A. W., Hidayah, I., \& Asikin, M. (2020a). Developing mathematics learning materials of fifth grade of elementary school integrating mathematics game, problem posing, and manipulative. Journal of Physics: Conference Series, 1567(2). https://doi.org/10.1088/1742-6596/1567/2/022089

Kurniasih, A. W., Hidayah, I., \& Asikin, M. (2020b). Developing mathematics learning materials of fifth grade of elementary school integrating mathematics game, problem posing, and manipulative. Journal of Physics: Conference Series, 1567(2), 22089.

Kusumadewi, R. F., Ulia, N., \& Ristanti, N. (2019). Efektivitas Model Pembelajaran Discovery Learning Terhadap Kemampuan Literasi Matematika di Sekolah Dasar. Sekolah Dasar: Kajian Teori dan Praktik Pendidikan, 28(1), 11-16.

Muslim, A. (2020a). The effect of cooperative learning Type Teams-Games-Tournaments (TGT) on mathematical connection and communication ability in elementary schools. Journal of Physics: Conference Series, 1469(1). https://doi.org/10.1088/1742-6596/1469/1/012170

Muslim, A. (2020b). The effect of cooperative learning Type Teams-Games-Tournaments (TGT) on mathematical connection and communication ability in elementary schools. JPhCS, $1469(1), 12170$.

Nurdyansyah, N., \& Fahyuni, E. F. (2016). Inovasi model pembelajaran sesuai kurikulum 2013. Nizamia Learning Center.

Permatasari, H. R., \& Wahyudin, W. (2017). Gender: Its relation to Mathematical Creative Thinking Skill. Journal of Physics: Conference Series, 895(1). https://doi.org/10.1088/17426596/895/1/012093

Primandari, P. A., Sulasmono, B. S., \& Setyaningtyas, E. W. (2019). Perbedaan Pengaruh Model Kooperatif Tipe Tgt Dan Stad Dengan Multimedia Interaktif Ceria Terhadap Sikap Sosial Dan Hasil Belajar Kognitif Pada Pembelajaran Tematik Kelas 5 SD. Jurnal Basicedu, 3(1), 83-91.

Sari, P. N., Sukma, E., \& Fitria, Y. (2018). Pengaruh Strategi Directed Reading Thinking Activity (DRTA) terhadap Kemampuan Membaca Pemahaman Siswa Kelas V Sekolah Dasar. $e$ Journal Pembelajaran Inovasi, Jurnal Ilmiah Pendidikan Dasar, 6(2).

Septiawan, I. M. A. E., Rati, N. W., \& Murda, I. N. (2017). Pengaruh Model Pembelajaran Kooperatif Tipe TGT Berbantuan Media Audio Visual Terhadap Hasil Belajar IPA. MIMBAR PGSD Undiksha, 5(2).

Sinambela, P. N. J. M. (2017). Kurikulum 2013 dan implementasinya dalam pembelajaran. Generasi Kampus, 6(2).

Triowathi, N., \& Wijayanti, A. (2018). Implementasi Team Games Tournament (TGT) dalam Meningkatkan Kerjasama dan Hasil Belajar IPA. Jurnal Pijar Mipa, 13(2), 110-118.

Zulfadewina, Sucipto, A., Iba, K., \& Zulherman. (2020). Jurnal basicedu. Jurnal basicedu, 4(4), $1308-1314$.

Zulherman. (2018). Physics Module Design of Wave Subject for Secondary School. Jurnal Ilmiah Pendidikan IPA, 8(2), 143-148. http://dx.doi.org/10.30998/formatif.v8i2.2305 Physics

Zulherman, Arifudin, R., \& Pratiwi, M. S. (2020). Jurnal basicedu. Jurnal basicedu, 4(4), 12671273. 